\title{
Editorial
}

\section{A diez años del asesinato de los jesuitas de la UCA}

Hace diez años se perpetró un crimen horrendo en El Salvador: un grupo de militares, siguiendo órdenes del alto mando de la Fuerza Armada, asesinó a seis jesuitas y a dos colaboradoras suyas. Estas muertes se sumaron a las de miles de salvadoreños y salvadoreñas - campesinos, obreros, religiosos, profesionales, estudiantes- que, desde mediados de la década de los años setenta hasta la firma de los acuerdos de paz, en 1992, fueron víctimas de la irracionalidad, la prepotencia y el odio. La saña con la que fue cometido el crimen, así como el contexto que lo propició -la ofensiva hasta el tope del FMLN, la reacción violenta del ejército y la cadena nacional que llamaba a exterminar a los sospechosos de atentar contra el orden establecido- pusieron de manifiesto los extremos niveles de deterioro social y ético a los que había llegado el país debido al imperio del autoritarismo y a la intransigencia de quienes no tenían más opciones para producir cambios en la sociedad que la lucha armada revolucionaria.

Recordar a los jesuitas y a sus colaboradoras, honrar su memoria, supone y exige recordar y honrar a esos miles de compatriotas que murieron antes que ellos. Eso, lejos de opacar el significado de su asesinato, lo realza, lo sitúa en su verdadero contexto: el de la muerte violenta de quienes trabajaron incansablemente, y muchas veces desde el anonimato, por una sociedad más justa y solidaria. La muerte de los jesuitas de la UCA - Ignacio Ellacuría, Ignacio MartínBaró, Amando López, Segundo Montes, Juan Ramón Moreno y Joaquín López y López, así como de Elba y Celina - no fue un mero accidente, un descuido, un entor de cálculo. Se trató de una asesinato inscrito en una lógica institucional de 
terror y muerte, desde la cual los jesuitas eran considerados unos enemigos más a exterminar, al igual que lo habían sido Monseñor Romero, los dirigentes del FDR, y los sindicalistas de FENASTRAS.

A diez años de aquel terrible crimen —un crimen que terminó con la vida de hombres honrados con ellos mismos y con la realidad-, es necesario insistir sobre la lógica institucional que llevó a la concreción del asesinato, así como sobre la responsabilidad de quienes la pusieron en marcha. Hay que dejar claramente establecido que no se trató del error de unos cuantos, sino de un ejercicio más de terror amparado por miembros de la más alta jerarquía política y militar. Había un aparato institucional de terror y muerte y había quienes dirigían, desde las instancias estatales superiores, su funcionamiento.

Obviar esto, es decir, ver el asesinato de los jesuitas como resultado de un desquiciamiento pasajero de un grupo de militares confundidos por la situación, es perder de vista lo más importante que ese crimen puso en evidencia: que quienes concentraban el poder político y económico en El Salvador -los militares y la oligarquía - estaban dispuestos a aniquilar a cualquiera que cuestionara ese poder. Aniquilar, exterminar, no dejar sobrevivientes: eso fue lo que hicieron con los jesuitas, con Elba y Celina. Dicho de otro modo, con los jesuitas y sus colaboradoras se pusieron en marcha, una vez más, los mecanismos de aniquilación de los que se habían servido durante décadas los grupos de poder económico y político (militar). Fueron esos mismos mecanismos los que dieron lugar al genocidio de principios de la década de los años ochenta.

En este sentido, hay que esforzarse por entender el asesinato de los jesuitas en su verdadero contexto. Por un lado, este crimen nos remite a los miles de salvadoreños asesinados en las dos últimas décadas por desear un país distinto, un país donde imperaran la justicia y la solidaridad. Los jesuitas, aunque expresaron singularmente ese deseo — por su talante intelectual, por su vocación cristiana, por su entrega a un país que adoptaron como suyo-, no estuvieron solos en su esfuerzo ni solos en el sacrificio. Otros los precedieron en el esfuerzo por construir los cimientos de una sociedad más humana, siendo muchos de ellos asesinados, torturados y desaparecidos. Por otro lado, en su asesinato se concretó una lógica institucional diseñada para doblegar, a través del terror y la muerte, a quienes propusieran altemativas a las violencias estructural, institucional y terrorista vigentes en El Salvador. Ciertamente, esta lógica se ejerció implacablemente sobre los jesuitas, pero ya antes había mostrado su efectividad con miles de salvadoreños indefensos.

Desde la muerte de los jesuitas, muchas cosas han cambiado en El Salvador y en el mundo. Aun en el caso de quienes abanderaron las ideas más audaces, las propuestas de cambio social radical han sido suplantadas por posiciones de compromiso con aquellos que fueron sus enemigos mortales en el pasado reciente. Así, las diferencias entre quienes hasta hace poco defendían proyectos socio- 
políticos distintos se han desdibujado, cerrando las opciones para unos ciudadanos cada vez más golpeados por la precariedad económica y la inseguridad.

Dicho de otro modo, la conversión (el réciclaje) de la izquierda armada no ha sido sólo hacia la democracia, sino también hacia el neoliberalismo en sus manifestaciones más perversas. En este proceso, la izquierda en su conjunto ha terminado por ser algo menos que un actor pasivo en un orden socio-económico controlado por los grupos de poder económico. Entre tanto, la derecha, sin resistencias importantes, se ha dedicado a hacer lo que más le gusta: amasar grandes fortunas valiéndose de todos los medios a su alcance. Algunos de sus miembros, responsables y/o cómplices de asesinatos, desapariciones y torturas en las dos décadas pasadas, se presentan con el mayor descaro como los adalides de la democracia. Con la ayuda de un sistema judicial viciado han hecho un borrón y cuenta nueva con su pasado, como si con sus crímenes no hubieran causado daños irreparables en el tejido social. Es indudable que tienen una deuda pendiente no sólo con las familias directamente afectadas, sino con el conjunto de la sociedad. Y es que la sociedad salvadoreña sólo podrá recobrar su dignidad si quienes la laceraron de múltiples formas son sancionados como es debido.

Tras la firma de la paz, los mecanismos institucionales de terror y muerte han sido alterados, aunque no con la suficiente radicalidad como para asegurar que nunca más van a volver a ponerse en marcha. Todavía existen espacios institucionales no sometidos totalmente a la legalidad y al control de la sociedad. El andamiaje de las instituciones democráticas —desde los partidos hasta el sistema de justicia - es sumamente débil, lo cual favorece la pervivencia de nichos de ilegalidad al interior de las estructuras estatales.

Asimismo, individuos y grupos que antes vivieron del exterminio de otros - subversivos, comunistas, "piricuacos"- tienen una presencia muchas veces decisiva, tanto en la esfera pública como en los círculos oscuros que quedan como herencia del pasado reciente. No paran de hablar de su credo democrático, son analistas políticos, comentaristas, conductores de programas de radio o televisión y hasta empresarios. Pero, cuando se escarba detalladamente en sus actividades, no son tan limpios y honestos como aparentan, al igual que tampoco lo fueron en el pasado. Añoran los tiempos en los que reinaban con absoluta impunidad y quisieran volver al pasado. Creen que las leyes no son para ellos, sino para los demás; desafían a los jueces, ocultan información, denigran a sus adversarios. En fin, son una amenaza para la institucionalidad democrática.

Sobran los que gritan a los cuatro vientos que ya no hay que seguir hurgando en el pasado, pues si se siguen tocando los viejas heridas éstas nunca van a sanar. Superficialmente, quizás las cosas sean así. Sin embargo, hay dinamismos históricos del pasado que configuran la realidad del presente tanto en el plano estructural como en plano simbólico. Muchas de las perversiones institucionales de ahora - por ejemplo, las que tienen atrapada a la Policía Nacional Civil- 
guardan estrecha relación con perversiones del pasado reciente. Muchas de las prácticas criminales de ahora - bandas de secuestradores, narcotraficantes, extorsionistas - no son ajenas a las prácticas que proliferaron entre los sectores militares, políticos y empresariales en la década pasada. Muchos de los valores de la cultura nacional actual - prepotencia, fuerza, matonería- se incubaron durante el largo reinado del autoritarismo militar. En otras palabras, el pasado no puede ser eliminado por decreto o por la voluntad de unos bienintencionados que quieren proteger a las generaciones presentes y futuras de los fantasmas que acosaron a sus padres.

Recordar a los jesuitas de la UCA - y con ellos a todos los asesinados por su compromiso con la justicia - es enfrentarse críticamente con el presente de El Salvador. Aunque la guerra terminó e importantes garantías democráticas se han establecido, quedan muchas cosas aún por hacer. Quedan puntos oscuros por aclarar y responsabilidades por establecer. Quedan cuentas pendientes por saldar. Y todo esto para dignificar a una sociedad que ha sido violentada $y$ maltratada durante largo tiempo sin que aún se haya hecho justicia. 